\title{
IS SUSILA BUDHI DHARMA (SUBUD) A RELIGION?
}

\author{
Watini \\ Center for Religious and Cross-cultural Studies, Gadjah Mada University \\ Email: watini@mail.ugm.ac.id
}

\begin{abstract}
The government of Indonesia has recognized six offical religions based on certain categories by law. Susila Budhi Dharma known as SUBUD is not included as one of them. The debate on the inclusion of SUBUD as a religion has existed since its existance. This work attemps to explore the experience of SUBUD in dealing with the acknowledment both by people and the schoolars in religious studies and the discource on it. Richard King believes that Subud is a religion since there is mysticim in it (submission to God) with latihan kejiwaan. He may say that it is constructed like what laso is prascticed in Christianity. Subud is not a religious teaching claimed by Subud's members but Subud is as a religion since the latihan kejiwaan is from God and appropriate with God's will. In the discussion of Marxian, Durkheimian and Freudian, Subud is considered as a religion since it tends to promote dependance and can disturb economy. While in the views of both Weberian and Eliadean, SUBUD is considered as a religion because it is related to sacred intities and is traditonalism. The works suggests that deeper information would be beneficial for the people within religious studies to accommodate Subud as a religion based on theories in the field. Talal Asad's theory can develop Subud terminology that it is as a religion since it is categorized as an organization that have structures of leaders and people. Indeed, Subud has proven to separate from the states for its growing and developtment in European countries and the USA.
\end{abstract}

Keywords: SUBUD, Religious Studies, Java, religion.

\section{INTRODUCTION}

Aliran kepercayaan is a federation of about 353 Javenese mystical sects and has been recognized by the Indonesian government as a formal institution since 1987. As quoted by Patty, Samuel writes that it was put under the charge of the Ministry of Education and Culture instead of the Ministry of Religious Affair (MORA) as the one dealing with religion in Indonesia. And the Muslims do not agree to the idea of Subud to be accepted as a religion and included in the MORA. He also mentions that political instability and socio-economic 
deprivation have played a major role in the growth of the movement. Subud is not recognized as religion because it is an aliran kepercayaan or a mistical belief sect. But Subud is a new religious movement (Patty, 1986, iv-v). Although Subud is not recognized as a religion, it vontinues to grow until today. Patty also describes that aliran kepercayaan is a term to refer to groups of people who draw upon Javanese culture traditions, trying to define their own belief system outside of Indonesian's official religions like Islam, Christianity, Hinduism and Budhism (Patty, 1986:1).

After the independence day, Indonesia takes the Vive Principles known as Pancasila as a foundation of the country that includes; believing in one god, humanism, nasionalism of Indonesia, democracy and social justice. Believing in one god means that the government would give freedom for all religions to express their doctrine and the Government would also finally support all religions which had been accepted as "official religions" in the country: Islam, Catholicism, Protestanism, Hinduism, Buddhism and later on Confucianism. Because of that, the Ministry of Religious Affair proposes an official definition of religion. Groups that need acknowledgement as a religion should have particular requirements such as having a prophet, a holy scripture and international recognition (Patty, 1986:1).

In colonial era, Islam became the object of bureucratization and administration so Kantoor voor Inlandsche Zaken was made. The first director is Snouck Hurgronje. Native Indonesian call that institution as "The Office of Religion (Kantor Agama) and then later became Department of Religion (Sihombing et al 2008: 73-74). Today it is known as Kementrian Agama or the Ministry of Religious Affair (MORA). Kantor Agama's establishment was intended to manage the administration of people and their religious affairs. Yet, in that time, kepercayaan or kebatinan has existed. For this special group of kebatinan, the government established what was called Pengawas Aliran Kepercayaan Masyarakat (Pakem).

The members of the Pakem was legalized pasca independence day but the essence of the idea had existed since the colonial era. The initiator was Snouck Hurgronje (Sihombing etc, 2008, 73). Pakem is mentioned in Pokok-pokok Pola Pelaksanaan Tugas Pakem (the duties of Pakem) and that aliran keagamaan is a sect of a religion, religious movement, group of religious community. Pakem was also recognized by Kejaksaan Agung Republik Indonesia mentioning that "Aliran keagamaan teaching is based on a constitution as a holy book. The holy book of aliran kepercayaan includes spirituality (kerohanian) that grows and is embodied in a society as a result of ciptarasa, karsa, and hasil karya manusia (result of human's creation) (Jakarta:Kejaksanaan Agung RI, 3 in 
Nurdjana 2009:20).

Nurdjana states that aliran kepercayaan is coming from all branches (madzhab, sect, ordo, ism et cetera) of faiths in a society either coming from a religion or non-religion. The group would have activities related to mistic, Javenesse, forecasting, paranormal and metaphysic $(2009,21)$. This paper employs Nurdjana's term to explain aliran kepercayaan in Yogayakarta that is called SUBUD (Susila Budhi Dharma).

\section{SUBUD AND WILFRED CANTWELL SMITH}

According to Smith (religion is something (noun) that is reified from religious (adjective) which comes from large thing to very limited thing. Many scholars believe that the term of religion comes from "religio" such as St. Thomas Aquinas. He states that scholars do so by omitting not only the vitality but the most significant of all factors in that vitality, namely its relation with transcendence (Smith, 124). The differences between religion and religions is that religion is a belief in God but religions is what a differential all religion is. "Religio" until now becomes so limited that makes it very limited and materialized and standardized.

Zainal Abidin Bagir (2016) agrees with Smith that word "religion" refers to Christian Faith then is reified and applied in religions which is found in the West. It is a shaping new entity from that reality through the uses of one category. Therefore it shapes the ontology of religion. For instance, Hinduism is a tradition from India which is very kind and it is called by England imperialism by 'Hinduism.' Yet, it is not the case for Islam by calling it "Mohamedanism." Jerome agrees that religion refers to "believe", experience and related to God. Reification is standardized with criterias of reification and finds the essence of the truth of a religion. Criteria of reification is sacred "sui generis" that is "divine" and have a sacred and profane (spirit). For example, Hinduism is reified by the scholars that it is not invented by Hindus. The implication of reification in Indonesia is the existence of six religions which are the cumulative religions. This view is influenced by Snouck Hurgronje who separated religion from adat. The benefit of reification is to make the definition becoming easier (Bagir 2016: 26).

The impact of reification initiated by Smith is that many kepercayaan or kebatinan_can be categorized as religion. Reification have requirements in religion. Kepercayaan can be categorized as religion if coming with prophets, holy books, believe in one God and so forth. Based on Smith's theory, Subud is not a religion because Subud is not affordable to reify as a religion. The 
fourth Congres of BKKI (the groups of Kebatinan), in Malang East Java, in July 1960 finds that there was no essential difference between "religion" and Kebatinan because religion emphasizes the ritual while kebatinan stresses in inner-experience and the perfection of man. If using the terms from the state of Indonesia, Subud is not a religion because in 1960, the ministry of Religion proposed a definition of religion with the purpose of denying Kebatinan as a religion (Patty, 1986: 4). To the Ministry, Subud is not a religion because Subud doesn't meet some requirements to be called as a religion. A group should have a prophet, worship the Almighty Oneness of God and has a holy scripture and a system of laws for its follower to be recognized as a religion. Therefore, in 1960 there was an establisment of an organization called PAKEM that is an acronym for Mystical Supervision (Pengawas Aliran Kepercayaan Masyarakat) to protect the existing religions from the influence of negative aspects of the mystical sects (Patty, 1986: 4). In 1978, Aliran Kepercayaan including Subud was accepted officially by the government throuh the Proples' representativese Assembly (Majelis Permusyawaratan rakyat or MPR) as a formal institution but not as a religion.

The government acceptance to Aliran Kepercayaan as a formal institution is a very important point. It means that the government supports the group along with the other religious groups in the country although part of muslims in the Department of Religion opposed Subud as a formal institution with strong opposition of the Islamic group and the dominance of the Muslims in the Department of Religion (Patty, 1986: 11). In 1961, there was the fifth congress of BKKI. They built the Federation of Congress Kebatinan Indonesia (the Gabungan Musyawarah Kebatinan Indonesia or GMKI) that is concerned in education, information and politics. In that period, the BKKI was infiltated by Communists (Patty, 1986:71-72). Based on Patty's writing (1986:115) we can conclude that Subud has different concept from other groups of Aliran Kebatinan because as its founder claims that it is only a method to help people achieve the truth of God in all religions and its role is to bring harmony to different religions. Subud has members that come from different religious backgrounds who live together with harmonious relationship.

The implication to Subud member is that member's of Subud is investigated by neighborhood that Subud is heretical action especially in branch of Subud in Yogyakarta. In Checoslovakia, Subud is investigated by police (Sullivan 1991: 36 ). Thus, organization of Subud is monitored by state.

\section{SUBUD AS RELIGIOUS PRACTICE}

Subud is the first and the only Indonesian spiritual brotherhood that has gained 
extensive influence and a great number of followers in Indonesia as well as abroad. The founder of Subud is Bapak Subuh Sumohadiwidjojo. He was born in Semarang. Subud had been acknowledged by the state on 19 October 1964 in Jakarta. Muhammad Subuh remains in Semarang then move to Yogyakarta and the last move to Jakarta until he died (Batubara, 1999).

"Latihan" or practice is a commonplace word in Indonesia meaning any form of exercise such as physical exercise or learning lessons at school. "Kejiwaan" means spirituality. Subuh Sumohadiwidjojo explains that the final goal of latihan is menunggalkan. The term menunggalkan is a transitive verb derived from the noun tunggal that means single or singular (Kafrawi 1970: 147). Latihan kejiwaan is a method or way to submit to God. It is a manifestion which we obey to the merciful of God (Arifianto, 2012: 2). The occasion when new member join Subud and do the latihan for the first time is referred to as your "opening", and is generally understood by Subud members to be a direct contact with the Power of God which initiates and guides this form of worship. Men and women do the latihan separately. To practise the latihan, members stand relaxed theirself, or with a group, and follow whatever arises spontaneously from within theirself. The experience is different for each person and different for a particular person at different times. Some people report an inner vibration, or a feeling like electricity running through their bodies. Some feel an impulse to move, utter sounds, to laugh, cry, sing, dance or pray. At other times the latihan can be a very quiet inward experience.

The latihan usually continues for about thirty minutes and is usually done twice a week with the group. After experience has been gained, some people do an additional latihan by themselves once a week. The effects of doing the latihan also vary greatly. For some, it brings about a peaceful, gradual development. For others, it initiates a process of dramatic change in their lives. Sometimes, difficulties must be faced as the process of purification begun by the latihan takes its course. People usually have a feeling of relaxation and well-being immediately after doing the latihan. In the longer run, they may come to trust the guidance received through the latihan as it permeates every aspect of their lives including personal relationships, family life and work.

People also need helps for doing the latihan. Helpers give explanations about the basis and aims of the latihan kejiwaan of Subud for those who are interested in joining. They open people who have completed the waiting period and attend their latihan until they are really able to feel and receive the latihan. They come to the latihan place whenever there is an opening of people who have completed the waiting period.

Symbol of Subud is also unique. Within the circle are also depicted seven 
inner circles, which illustrate the existence of forces, or spirits (roh), which also return to their origins. And it is these circles within the symbol, seven in all, which depict the existence of certain forces, which are, beginning from the material force (roh kebendaan); the vegetable force (roh tumbuh-tumnuhan); the animal spirit (roh hewani); the ordinary human force (roh orang); the spirit of the perfect human being (roh rohani); the spirit of higher than that which is called roh rahmani; and the spirit higher than all the rest, the roh rabani spirit. In a talk on December 141957 in England, Bapak Susilo gave an explanation about the meaning of the Subud symbol. He said that the meaning of Subud is "Originating from its source and returning to the same source". And this is represented in the Subud symbol as something round, a circle, meaning "limitless and forever returning to its origin". And in this symbol something else is represented as well: that we do not stop on the way, but rather we go on without limit. This means we do not hold anything back, but everything is for God, from God.

The doctrin about Merciful God in Seri Pembinaan Penghayatan Kepercyaan Kepada Tuhan Yang Maha Esa number 26 P\&K department states includes God is the One, the Great, the Creator. According to events that is done in latihan kejiwaan, only God that have to be submitted and only God that can lead and repair and treat body and soul of human. All nature is creates by God, the One. All creature in the world and place after the world is wished of God. (P\&K Department, Jakarta: 46 in Nurdjana 2009: 92). Implementation of SUBUD is a leading by God but the goal of SUBUD is to submit to God through latihan kejiwaan. SUBUD as latihan kejiwaan is taught and led by God (Alif, 1988:2-3).

\section{SUBUD AND THE DISCUSSION OF RELIGION AND SOCIAL THEORIES}

According to Tylor, Subud is a religion because there is monotheism that includes the development of animism-polytheism- monotheism. Taylor states that the origins of religion is animism (Tylor, 29-30). Frazer theory recognizes Subud as a religion, it is because Subud has experience suas as magic (illogical) because the experience of Bapak Muhammad Subuh is similar to Prophet Muhammad that he went to somewhere in the night and he received something like light. Frazer states that the origin of religion is magic. Frazer says that the principle of magic is based on two things; something that like produces like, or that an effect resembles it causes; that things which have once been in contact to act on each other (Frazer, 40). In this case, the magic is supposed as blac magic or klenik as a part of Javanese Mysticism. In the third Badan 
Kongres Kebatinan Indonesia (BKKI), the congress thereupon reiterated that Kebatinan was not a black magic or klenik but supernatural power and white magic (Patty, 1986:3).

There are different argument from Durkheim and Mircea Eliade, and even oppositing each other. Durkheim states that something which is sacred is contructed by people not by individual. Anything individual is profane. Mircea Eliade claims that daily activities of human is profane. There are different perspective from other scholars. Eliade states that Epyphany is real of the religion and axis mundi (Eliade, 273) is center of the world (connect others). He also mention that "sui generis" is something tremendous fascinating and it could be many places. Weber provides the typology of religion into two categorizes; modern and traditionalism (Weber, 260-263). $\mathrm{He}$ also concerns in terms of charisma. Charisma is very revolutionary that can change suddenly. Weber describes that charisma is categorized as a defender. Its concerns perspective phenomenon in different time. Weber focuses on the essence of religion, not on "what the religion is". Mircea Eliade and Weber defend religion as a "sui generis phenomenon" (Maarif 2016: 5). Weber sees religion as the "cause."

In Contemporar time, Eliade improves her theory in modern world that is not only discuss in the historian of religion but also politic and social historian such as psycholigist and philospher. According to both Weber and Eliade, Subud is a religion because it is related to sacred and it is traditonalism. Subud has latihan kejiwaan, and latihan kejiwaan has relations with God. People who do latihan kejiwaan receive movements that come from God and are appoprite with God's will.

The other schoolars; Frued, Durkheim and Marx; are some of those holding theories on religion. They seem to believe that the category of religion is constructed. Religion is a constructed reality (not exactly from society) (Marx, 143-144). They see religion as an "effect" (Maarif, 2016). Marx argues that religion is if anything the chief offender and religion employs its skills to deflect the anger (Marx, 144). Freud describes that trauma is one of symptom that consequences from the phenomena of religion (Freud, 94). Marx, Durkheim and Freud define religion in different ways because they see that religion has no benefit to people, and even religion tends to create dependency (Durkheim, 15). Durkheim argues that religion is like an aggreement of certain groups of people. They decide a value and name it as a religion that contain rites and beliefs. The other component of religion is magic. Religion is a system which balances between belief and practice (Durkheim, 29-30). Thus, based on this theory Subud is not religion. As discussed earlier, Subud then is considered as 
Kebatinan, not black magic or klenik but supernatural power and white magic (Patty, 1986:3).

Formations of Secular -Christianity, Islam, Modernity is written by Talal Asad which is published in Stanford University in 2003. Talal Asad quotes his writing in Jose Casanova's book which is explained development of modernity since Weber era. There are three elements: 1). Increasing structural differentiation of social spaces resulting in the separating religion from politic, economy, science and et cetera. 2) privatization of religion within its own sphere. 3). Declining social significance of religious belief commitment and institution. Casanova states that Element 1 and 3 air viable. The legitimate entry of religion results in modern "hybrids": the principle of structural differentiation, according to which religion, economy, education, and science are located in autonomous social spaces. Element 1 and 3 as secularization thesis is falls. Asad argues that nation is said to be under God. Nature and culture is two essence things which is used by nation. If nature and culture (socity) is separated, so it is called modernity as Bruno Latour said (Blok and Jensen 2011:52). Asad also writes about Islam that Islamism and Arab nationalism concern in modernizing state. Both Asad and Latour use anthropology method.

Another interesting arguent comes from talal Asad. Asad notes that secularism affects the study on religion. Religion has produced influences on politics and likewise. The role of secularism is the construction of religion where religion is studied in academia. The notion of secularism is that there is relatoinship between religion and nationalism. Asad believes that secularism and religion is not necessary to collide like what has happened in Indonesia. He criticizes Taylor that secularism is close with nation state (Asad 2003: 2). Secularism is separation bertween religion and state but in public (morality) and in religious law there is a phenomena as normally called as hybrid. Religion could appear in many domain including politics and education. The needs is to bring the study of religion to that context. This Asad theory can develop Subud terminology to become apart of the practice of a religion.

The last scholar I would like to discuss here is Richard King. He writes that orientalism occurs because of the sitiation of politic, economy, cultural power of English and English language in the world. In the early time of orientalism, many people in India stand against English. Indians say that their country is theirs. They did not accept orientalists. King quotes in many place from Chakrabaty, it is interesting because religious studies contributes to the construction of its object of its analysis (orintalism) (King,1999, 82). King quotes Edward Said that orientalist is everyone who teaches, writes and 
research the Orient. The impact of orientalism is that English has become a powerful international language (King 1999: 217). King states that there is mysticism in India. Mysticism is one of religious studies that has defined the way of religion. King wants to see how orientalism is placed in India. How mysticism defined is same as the way how religion defines. Mysticism is also about experience. The construction of mysticism in the East is made by the West somehow. The way that Christianity is defined is used to represent the religion in the East. King looks everything universally see it in essence. Religius studdies tend to see phenomena as universal phenomena. Orientalism is about interaction between East and West. It is real problematic things if definition of religion is universally applicable. The essence effect is same thing with Smith that religion is true of right. Because of orientalism so Subud grows and develops in Europe and the USA. Subud it is not a religion although according to King Subud has a mystical aspect embedded on it (submit to God) with latihan kejiwaan so that some may say that it is constructed like misticism in Christianity (El-Hafidy 1982: 63-64).

\section{SUBUD IN RELIGIOUS STUDIES}

Bourdieu, as quited by Wijsen, claims that he does not see the distinction between theology and science of religion in the prespective of insider or outsider. If the essential notion of religion from a postmodern perspective doesn't use a certain boundary, both of them become blurred. It is not about the distinction about engaged or disengaged but the differences is about the research perspective or view of science, empirical or hermeneutic, or explanatory versus interpretative science. Wijsen (2013) sees that what makes a theologian a theologian is the practice of methodological conversion as distinct from methodological agnosticism. According to Wijsen, theology has important position in religious studies. Theology is emic but religous studies is ethic and theology is insider but religous studies is outsider. Wijsen supposes that the study of religion should employ methodological agnosticism or conversion but the most applicable methodology is methodological agnosticism. The total methodological agnosticism is done by Snouck Hurgronje. Theoloogy and religious studies are to complete each other. Both of religious studies and theology cannot be separated becausee religious studies put theology and theology is part of religious studies. There is no point bertween theology and religious studies but both of them is about methodological of theology, religious studies and comparative religion (Wijsen, 2013).

According to Frans Wijsen, there are two alternatives that African and European epistemologies can be reconcited or where this proves imposible 
they can exist in mutual acceptance of their differences. This paper will discusses: 1. The distinction between theology and and religious studies, 2. The distinction between insider and outsider perspectives in the study of religion, 3. The distinction between seminary and university of theology, 4 . The distinction between simplex and duplex ordo system, 5 . The distinction between empirical and hermeneutic studies of religion. 6. The distinction between methodological agnosticism and methodological conversion. For example, St. Anselm states that theology is faith seeking understanding. There are different perspective from academic study of religion which religion as social (Tylor, Durkheim), economic (Marx), psychological (Freud). Those all are very suitable theory to analyzed Subud, so researcher have deeper information. So Subud can be accommodated with that theory.

One of the importances of religious studies is that it provides concepts to explain action of human beings such as mystic in East tradition. In this case of Subud, Barbara categorizes Subud as moe of mystical movement and a typical product of the Javanese cultural environment (Barbara 1999:95). The leader of the Javanese Mysticism group (Kebatinan) which organized the Javenese Mystic Federation or BKKI was asked to become a member of Golongan Karya (Golkar) in Suharto era. Thus, the Aliran tried to unify all the Javanese Mystical groups in a broad single organization striving for legal recognition that culminated in the National Symposium on Kebatinan Mysticism, Science of the Soul and Science of the Spirit in Indonesia (Symposium Nasional Kepercayaan-Kebatinan, Kejiwaan dan Kerohanian Indonesia) in Yogyakarta in 1970. After that, the Kebatinan mystical group was accepted as an officially recognized institusion as a member of Golkar, the Gobvernment dominated political organization in December 1970. Then, the name Aliran Kebatinan was changed to become Aliran Kepercayaan (Patty 1986:10).

In religious studies, we can see that Subud is a religion based on the theories from some scholars that concern in relgious studies and try to define what religion is. In fourth Congress also, they discussed and tstated that there were no essential difference between Kebatinan and religion, namely that religion focuses on worshiping God in a formal ritual while Kebatinan focuses on the "inner-experience" of the individual and the perfection of man (Patty 1986, 71). Religous studies is important in this case because it is related to religion and can be explained as a reaction to the dogmatism and ritualism of the established monotheistic religions (Patty 1986: 73). Aactually, all of the Aliran Kepercayaan groups are worshiping God as people of other religions do. In term of religious studies, it is iportant to see that Subud as Javanese mystical sects pursuing inner-tranquility (ketentraman batin) and peacefulnss 
through meditation (Patty 1986: 158). One the helpers of Subud said that she joins Subud to control the inner power to solve his problems in daily life and to get hakikat which is spiritual needs.

\section{CONCLUSION}

The discussion of Subud and its relevant to the definition of religion is intersting and becoming important to the studies of religion, perticularly with regards to the teaching of misticism within religion. Subud as a unique phenomenon has taken us to the debate of wheter it is religion. Some argues that Subud is not a religion and some other do not so. The government of Indonesia uses the category of reification to see religion so that Subud is excluded from the terminology of a religion. In contrast, some scholars argue that Subud is religion since it carries out the teaching of mysticim with latihan kejiwaan. According to Marx, Durkheim and Freud, Subud is a religion because it can create dependancy. According to both theory of Weber and Eliade, SUBUD is religion since it is related to sacred things. It is the important poin in this conclusion that the discussion of the definition of certain practices of believe is being studied in the fields of religious studies. The case of Subud has shown to readers that the relation of nation and religion is still urgent to the discussion of the pratice of religion and or what it is called as Kepercayaan Kepada Tuhan Yang Maha Esa in Indonesian case. The sociological and anthropological aspects of religion are among other significant influences in the context of the studies of religious practices such Subud.

\section{BIBLIOGRAPHY}

Alif, M. R. (1988). Khatr Ilham, Bimbingan Getaran Hidup dari Kekuasaan Tuhan Yang Maha Esa Jakarta: Yayasan Penerbit "Kartika Bahagia" Arifianto, B. D. (2012). Human Passions, Sebuah Karya Film Tari. Unpublished Thesis. Pascasarjana Program. Yogyakarta: Institut Seni Indonesia.

Asad, T. (2003). Formations of the Secular: Christianity, Islam, Modernity (Cultural Memory in the Present). California: Stanford University Press.

Bagir, Z. A. (2016). Studi agama di Indonesia: Refleksi Pengalaman. Yogyakarta: Center for Religious and Cross-cultural Studies.

Batubara, C. (1999). Islam and Mystical Movement in Post Independence. Canada: McGill University.

Durkheim, E. (2009). The Elemantary of the Religious by Life Edward. B. Tylor in Pals, D. L. Introducing Religion: Readings from the Classic Theorists. 
New York - Oxford: Oxford University Press.

El-Hafidy, A. (1982). Aliran-aliran Kepercayaan dan Kebatinan di Indonesia. Jakarta: Ghalia Indonesia.

Eliade, M. (2009). Religion as Response to The Sacred in Pals, D. L. Introducing Religion: Readings from the Classic Theorists. New York - Oxford: Oxford University Press.

Frazer, J. (2009). Magic and the Rise of Religioin of Religion in Pals, D. L. Introducing Religion: Readings from the Classic Theorists. New York - Oxford: Oxford University Press.

Freud, S. (2009). Religion as Neurosis in Pals, D. L. Introducing Religion: Readings from the Classic Theorists. New York - Oxford: Oxford University Press

Frazer, J \& Weber, M. (2009). Religion and Culture Interwoven in Pals, D. L. Introducing Religion: Readings from the Classic Theorists. New York Oxford: Oxford University Press.

Jensen, A. B. \& Elgaard, T. (2011). Bruno Latour:Hybrid thoughta in a Hybrid World New York: Routledge.

Kafrawi, (1970). The Path of Subud. Unpublished Thesis. Canada: McGill University.

King, R. (1999). Orientalism and Religion. New York: Routledge.

Maa'rif, S. (2016). Syllabus of Academic Study of Religion, Yogyakarta: Universitas Gadjah Mada.

Marx, K. (2009). Religion as Agent of Economic Oppression in Pals, D. L. Introducing Religion: Readings from the Classic Theorists. New York - Oxford: Oxford University Press.

Mulder, N. (1978). Mysticism \& Everyday Life in Contemporary Java. Singapore: Singapore University Press.

Nurdjana, IGM. (2009). Hukum dan Aliran Menyimpang di Indonesia Yogyakarta: Pustaka Pelajar.

Patty, S. A. (1986). Aliran kepercayaan A Sosio religius movement in Indonesia. Unpublished Dissertation. Washington State University.

Sihombing, U. P. et al. (2008). Menggugat Bakor Pakem Jakarta: The Indonesian Legal Resource Center (ILRC), 73-74.

Smith, W. C. (1962). The Meaning and End of Religion. United States: First Fortress Press.

Tylor. E. B. (2009). Animism and the Origin of Religion in Pals, D. L. Introducing Religion: Readings from the Classic Theorists. New York - Oxford: Oxford University Press.

Wijsen, F. (2013). Editorial: Discourse Analysis in Religious Studies. in Journal Religion. Vol(43). Issue(1). 1-3. 